\title{
Geosites Inventory in Liguria Region (Northern Italy): A Tool for Regional Geoconservation and Environmental Management
}

\author{
Andrea Ferrando ${ }^{1}$, Francesco Faccini ${ }^{1, *(D)}$, Flavio Poggi ${ }^{2}$ and Paola Coratza ${ }^{3, *}$ (D) \\ 1 Dipartimento di Scienze della Terra, dell'Ambiente e della Vita, Università degli Studi di Genova, \\ 16132 Genoa, Italy; andrea.ferrando.8@gmail.com \\ 2 Dipartimento Territorio e Ambiente, Regione Liguria, 16121 Genoa, Italy; flavio.poggi@regione.liguria.it \\ 3 Dipartimento di Scienze Chimiche e Geologiche, Università degli Studi di Modena e Reggio Emilia, \\ 41125 Modena, Italy \\ * Correspondence: faccini@unige.it (F.F.); paola.coratza@unimore.it (P.C.)
}

Citation: Ferrando, A.; Faccini, F.;

Poggi, F.; Coratza, P. Geosites

Inventory in Liguria Region

(Northern Italy): A Tool for Regional Geoconservation and Environmental Management. Sustainability 2021, 13, 2346. https://doi.org/10.3390/ su13042346

Academic Editor: Mario Bentivenga

Received: 28 January 2021

Accepted: 18 February 2021

Published: 22 February 2021

Publisher's Note: MDPI stays neutral with regard to jurisdictional claims in published maps and institutional affiliations.

Copyright: (c) 2021 by the authors. Licensee MDPI, Basel, Switzerland. This article is an open access article distributed under the terms and conditions of the Creative Commons Attribution (CC BY) license (https:/ / creativecommons.org/licenses/by/ $4.0 /)$.

\begin{abstract}
The Liguria Region in Northern Italy is characterized by a wide geological and geomorphological variety, encompassing an important and valuable geoheritage. The Ligurian regional law (L.R. 39/2009) protects and enhances geodiversity and geosites, establishing the Regional Inventory of Geosites; however, an approved official inventory is still lacking. In this work, a first reasoned inventory of 120 geosites is proposed for the Liguria Region on the basis of field surveys and literature review. A quantitative assessment of the value and the degradation risk of geosites has been carried out: the value assessment takes into account scientific, additional and potential-for-use values; the degradation risk assessment considers geosites' fragility and vulnerability. The results, providing knowledge on the Ligurian geoheritage, can serve as the basis for the Regional Inventory of Geosites and can be useful tools for the implementation of any regional geoconservation strategy or environmental management plan.
\end{abstract}

Keywords: geosites; geoheritage; geoconservation; geotourism; Liguria

\section{Introduction}

Geodiversity, geoheritage and geosite studies have seen growing relevance in recent times, e.g., [1-4] and reference therein. Geodiversity, defined as the diversity within abiotic nature [5,6], is an important resource that can help the economic growth of a territory, for example, through the promotion of geotourism [7]. Geoheritage includes sites or areas, i.e., geosites, worthy of being protected and transmitted to future generations due to their special role in the reconstruction of Earth's history. The systematic collection and management of information about geodiversity and geoheritage of an area is a fundamental activity for the development of effective protection, conservation and enhancement strategies $[1,8]$.

Geoheritage studies have been carried out in many different environments. Most studies focus on terrestrial environments: coastal areas [9-15], mountain areas [16-18], karst areas [19-22], volcanic areas [23-26] and even urban areas [27-30]. In recent years research has been conducted on underwater geoheritage and marine geosites ([13] and references therein]) and on archaeogeosites, i.e., sites linking archaeological and geological interests [31-34]. New insights are being given on geosites risk of degradation and interaction with human actions [35,36].

The definition of geosites and the inseparable issue of their value have been much debated within the scientific community $[37,38]$ and references therein. The prevalent approach defines geosites as in situ geodiversity elements that have a certain value due to human perception and exploitation. According to this broad definition, the attributes that may confer value to geosite are scientific, scenic, socioeconomic, cultural, educational, the potential-for-use value. A more restrictive definition has been proposed by Brilha [8], according to which geosites are in situ elements with high scientific value. 
Many initiatives at the international level have emerged worldwide for the protection and enhancement of geodiversity and geoheritage. Worthy of note is the scientific program and initiatives approved and implemented by UNESCO since the early 1970s. The UNESCO Global Program is one of the most important and recent projects in this respect, as it aims to "promote a global network of geoparks safeguarding and developing selected areas having significant geological features" [39]. In fact, many recent geoheritage studies focus on areas to present as aspiring geoparks or to increase knowledge on the geoheritage of existing ones [40-44].

In Italy, for the last 25 years, there has been a growing scientific interest in topics related to geoheritage and a large set of territorial initiatives, both at administrative and scientific levels, have emerged, cf $[45,46]$. Italian sites with unique geological interests, such as Dolomites, Mount Etna and the Aeolian Islands, are known all around the world and, due to their outstanding geological features, have been proclaimed UNESCO World Heritage Sites [39]. In the national territory, there are currently nine Geoparks [47]. From a legal viewpoint, no specific national legislative instrument directly provides protection of geodiversity and geoheritage. However, a national activity of inventorying the most valuable sites of geological interest started at the beginning of the 2000s, handled by the Italian Institute for Environmental Protection and Research (ISPRA), which includes the Geological Survey of Italy). Currently, the Italian Geosites Inventory includes about 3700 geosites surveyed in the country, and the data are collected in a geodatabase freely consultable [48]. The national inventory is based on regional surveys and databases; however, several regional inventories are still incomplete and not exhaustive.

Liguria, the second smallest region in Northern Italy, is rich in natural and cultural beauty, and tourism is thriving. The region, often known as the "Italian Riviera", is characterized by a wide geological and geomorphological variety, encompassing a rich and valuable geoheritage and outstanding geological landscape. The protection of the geoheritage of Liguria is governed by the regional law (L.R. 39/2009), which promotes geosites and geodiversity protection and enhancement and establishes the Regional Inventory of Geosites. Despite a large amount of scientific publication on this region's geoheritage, e.g., [13,49-51] and the occurrence of one of the first Italian Geoparks, Beigua Geopark, the Liguria region still lacks an exhaustive regional inventory of geosites.

In this context, a study for the inventory and assessment of geosites, highlighting their values and degradation risk, in the whole Liguria region has been conducted, and the results are presented here. The main aims of this study are: (i) to increase knowledge of the Ligurian geoheritage, providing useful data for a comparison with Italian geoheritage; (ii) to contribute to updating and approval of the Regional Inventory of Geosites providing geosites' comprehensive information and data. The detailed data collected will be useful for setting-up effective environmental management for the protection and enhancement of the valuable regional geoheritage. Moreover, the methodological approach adopted in the present study could be adopted in other Italian regions or elsewhere for drawing up a similar catalog.

\section{Study Area}

The Liguria region (Figure 1), in northern Italy, is bounded to the NW by France and Piedmont and to the NE by Emilia-Romagna and Tuscany. To the S, the Liguria Region faces the Ligurian Sea, part of the Mediterranean Sea, with a $350 \mathrm{~km}$ long coastline. It is a very rugged land, with a continuous arch-shaped mountain chain formed by the Ligurian Alps and the Ligurian Apennines. The highest mountain (Mt. Saccarello, $2201 \mathrm{~m}$ ) is located in the Ligurian Alps; in the Ligurian Apennines, the highest elevation is reached by $\mathrm{Mt}$. Maggiorasca (1804 m).

The mountain chain constitutes the watershed between the Tyrrhenian-Ligurian basins and the Po River basin. The two sides of the mountain chain are very asymmetric: the southern maritime side is narrow and steep, while the northern Po riverside is wider and gentler. Because of this, the coastal rivers are short (from a few $\mathrm{km}$ to tens of $\mathrm{km}$ ), the most 
important being the Roja and the Centa rivers in the west and the Entella, the Vara and the Magra rivers in the east. The Po river tributaries are longer, the most important being the Tanaro, the Bormida, the Scrivia and the Trebbia rivers.

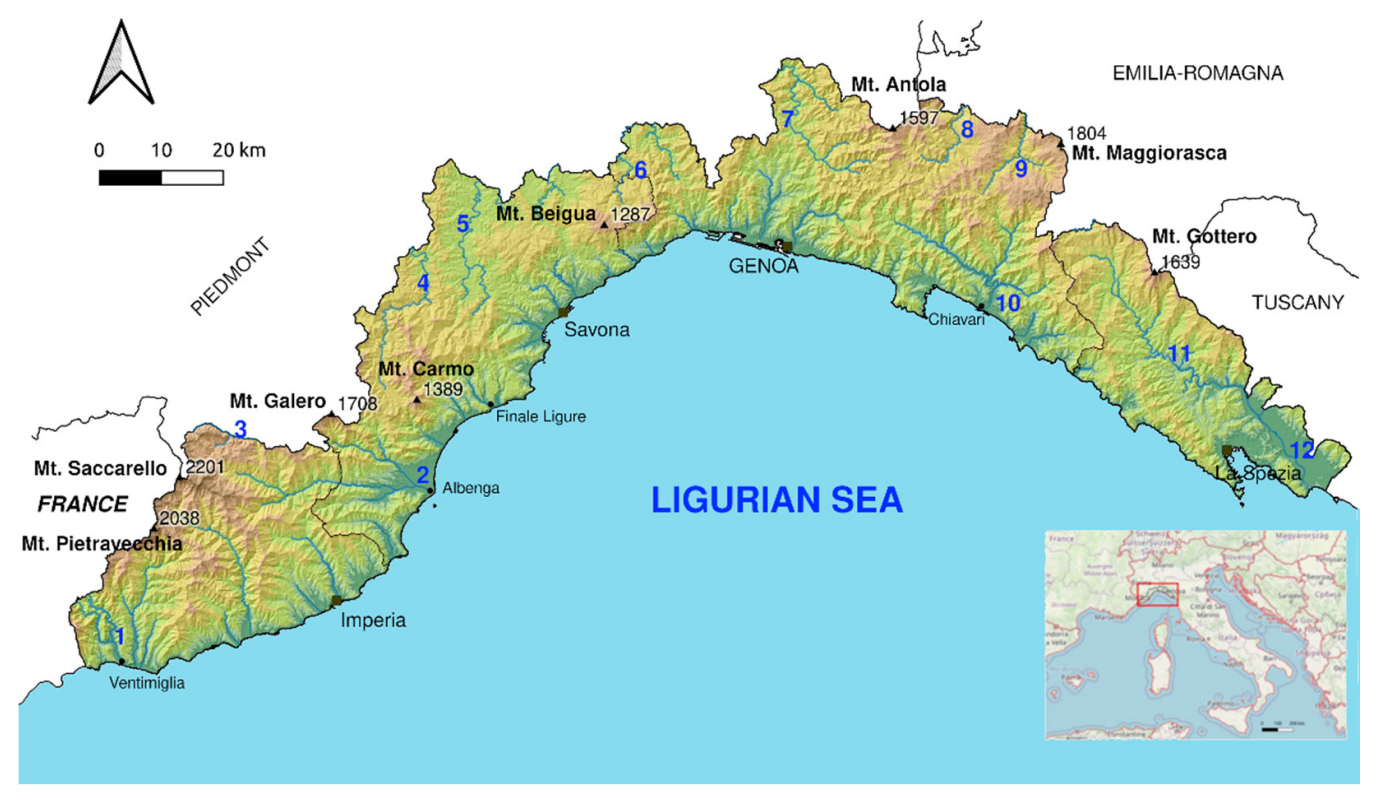

Figure 1. Map of the study area and indication of the main water courses: (1) Roya; (2) Centa; (3) Tanaro; (4) Bormida di Millesimo; (5) Bormida di Spigno; (6) Orba; (7) Scrivia; (8) Trebbia; (9) Aveto; (10) Entella; (11) Vara; (12) Magra.

The Ligurian climate is of the Mediterranean type, with several microclimates. According to the classification by Köppen [52], the coastal strip has a hot temperate climate, the southern side of the Alpine-Apennine mountain chain has a sub-coastal temperate climate, and the northern side has a subcontinental temperate climate [53]. The mountain areas higher than $1000 \mathrm{~m}$ a.s.l. are classified in the cool temperate climate.

The geological setting of the Liguria Region is complex, this region being the knot between two different orogenic systems: Alps and Apennines [54]. Three principal groups of tectonic units can be found, belonging to different palaeogeographic domains: the Palaeo-European continental units (Dauphinois-Provençal domain, Briançonnais domain and Pre-Piedmont domain), the oceanic units (Ligurian and Ligurian-Piedmont domains) and the Palaeo-African or Adriatic continental units (Tuscan domain) [55]. In the western part of the region, the tectonic units are affected by alpine HP-LT metamorphism, peaking in blue-schist or eclogite facies. The eastern units are non-metamorphic or affected by very low-grade metamorphism. A fault system named the Sestri-Voltaggio Line marks the separation between metamorphic and non-metamorphic units, and because of this, it has long been considered the Alps-Apennines boundary. Now there is scientific consensus that the Alps-Apennines junction occurs within a wide area, corresponding with the central Liguria Region, where the two orogenic systems have interfered [56,57]. In general, marly limestone flysch is the most abundant lithology, outcropping from Ventimiglia to Albenga and from Genoa to Chiavari. Sandstone flysch outcrops in the Vara valley and near Ventimiglia. Metamorphic ophiolites are found in the central part of the region, from Savona to Genoa (Voltri Massif), while non-metamorphic ophiolites outcrop in various places of the Ligurian Apennines, both as complete ophiolitic sequences and as blocks within sedimentary mélanges. Sandstones and conglomerates occur in the Scrivia, Orba and Bormida valleys and in Portofino. Limestones and dolomites are found mostly in western Liguria: in the Savona province and at the border between Liguria and France; in eastern Liguria, an important limestone outcrop is located around the city of La Spezia. Gneiss and amphibolites outcrop in the Province of Savona, forming the so-called Savona and Calizzano Massifs (Figure 2). 


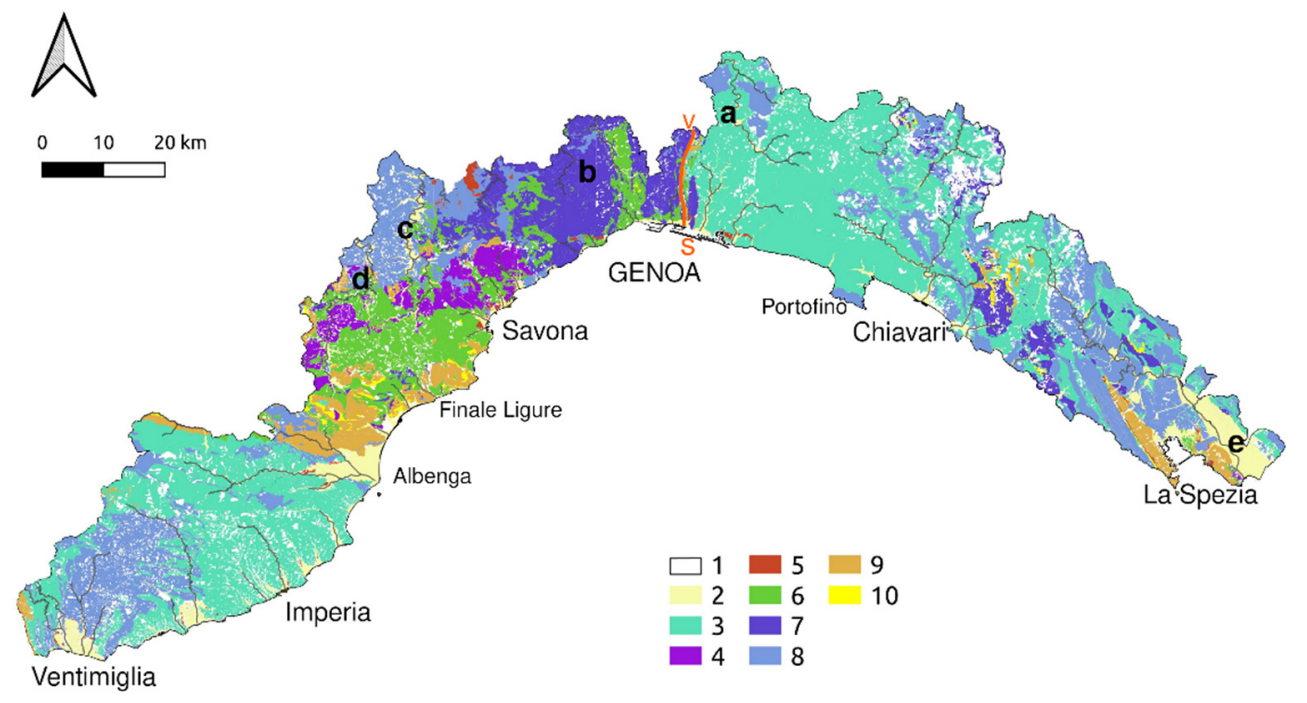

Figure 2. Lithological map of the Liguria region. (1) Debris cover; (2) alluvial and neogenic marine deposits; (3) Marly limestone flysch and chaotic complexes; (4) intrusive or massive metamorphic rocks; (5) marls and shales; (6) foliated metamorphic rocks; (7) ophiolites; (8) sandstones and conglomerates; (9) limestones, dolomites and evaporites; (10) Silicic rocks. S-V: Sestri-Voltaggio Line. Rivers: (a) Scrivia; (b) Orba; (c) Bormida di Spigno; (d) Bormida di Millesimo; (e) Magra.

The main tectonic lineations influence the hydrographic network: most watercourses show directions perpendicular or parallel to the main watershed [58]. Many watercourses show signs of recent tectonic activity, such as fluvial captures, entrenched meanders (Figure 3a). The main rivers form small flood plains next to their outlet, the most important being the Albenga plain (Centa River) in the west and the Magra plain in the east.
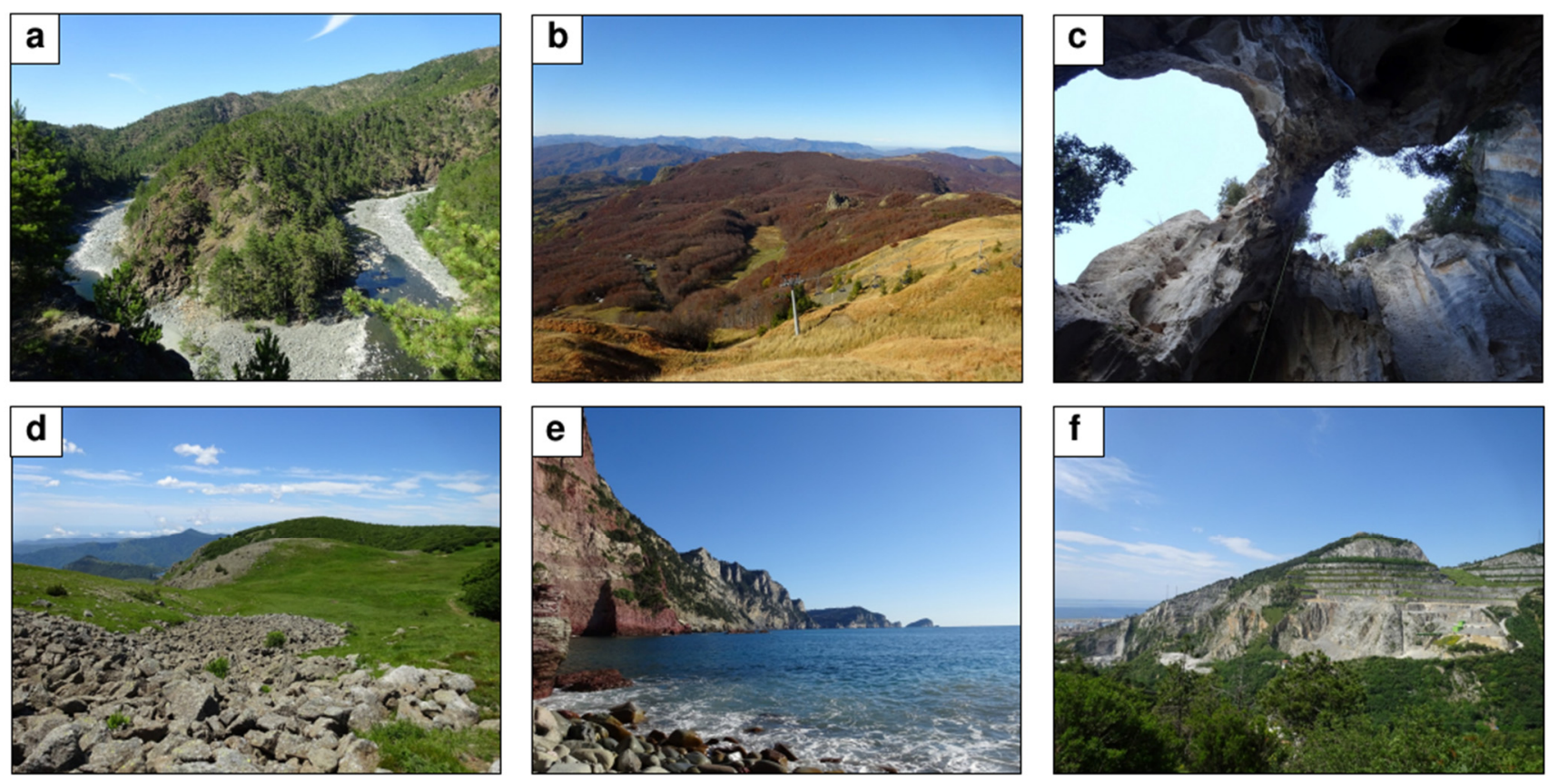

Figure 3. Main geological and geomorphological features of the Liguria region: (a) entrenched meanders (Orba river, Genoa metropolitan city); (b) deep-seated gravitational deformations (DSGD) trench (Prato della Cipolla, Genoa metropolitan city); (c) sinkhole and limestone arch (Grotta dell'Edera, Savona Province); (d) blockstream (Mt. Aiona, Genoa metropolitan city); (e) coastal cliffs (Portovenere, La Spezia Province); (f) dolomite quarries (Mt. Gazzo, Genoa).

In the Region, as many as 13,500 landslides have been cataloged [59]. The most frequent landslides are complex landslides, translational and rotational slides. Deep-seated 
gravitational deformations (DSGD; Figure 3b) and related landforms are widespread, especially in the eastern Ligurian Apennines [60]. The main limestone and dolomite outcrops are characterized by karst landforms; the most important karst areas lie in the Savona Province, where the main cave complexes are located (Mt. Carmo, Finale Ligure; Figure 3c) [61]. Many mountain areas, like the Beigua massif and the Trebbia and Aveto valleys, show signs of periglacial processes, such as blockfields and block streams (Figure 3d), wetlands, ponds and small lakes [62]. Poorly conserved relict glacial cirques can be observed in the Mt. Saccarello massif. The Ligurian coast is $350 \mathrm{~km}$ long and is mostly rocky, alternating promontories with high cliffs (Figure 3e) and bays with pocket beaches $[63,64]$. The small coastal plains are characterized by sandy beaches. By the main cities, long coastal sectors have been completely modified by human actions [65]. In the entire regional territory, anthropogenic landforms are frequent: urban areas, ports, airports, mines, quarries (Figure 3f), dumps, etc. The most widespread anthropic landforms in the inland are stone wall terraces, built for agricultural purposes [66].

\section{Materials and Methods}

In order to fulfill the needs and requirements of effective conservation and governance strategies of the geoheritage of a region, the systematic collection and management of information about the geosites are considered a crucial step [8].

In the scientific literature of geoheritage, a number of methodologies for geosites inventory, e.g., [15,67-69] and assessment, e.g., [8,70-81], with a great variety of purposes and at different scales, are available.

Based on these premises, a research program for the Ligurian geosites inventory and assessment of their value and degradation risk has been developed. The methodological approach adopted comprises the following operational phases (Figure 4): (i) recognition and selection of geosites based on three criteria: scientific interests, representativeness and spatial distribution; (ii) quantitative assessment of geosites; (iii) geosites' degradation risk assessment.

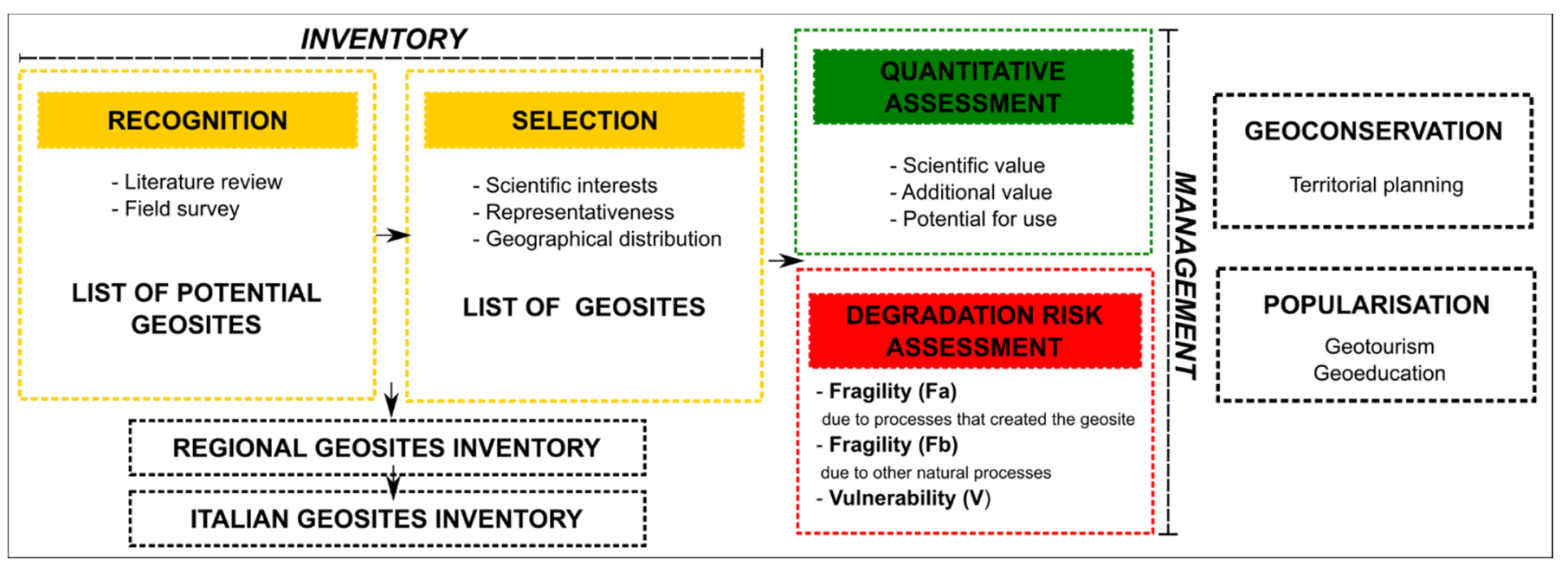

Figure 4. Block diagram with the main operational phases of the present research.

\subsection{Recognition and Selection of Geosites}

The recognition and selection of geosites in the Liguria Region have followed three methodological steps (Figure 4): (i) literature review and field surveys; (ii) compilation of a list of "potential geosites"; (iii) selection of the most interesting sites (i.e., geosites), that make up the final inventory.

The first phase took advantage of numerous works concerning the geology and geomorphology of the region and previous scientific and technical reports about geosites carried out by the Liguria Region, e.g., [51,82] and references therein and by Ligurian 
provinces, municipalities and natural parks $[13,49,83]$. Collecting all the data of previous field surveying and literature review, a database of "potential geosites" was compiled. From this large database, on the basis of the three following criteria, sites were selected to form the inventory of geosites:

- Scientific interests: the selected geosites must be well distributed by primary and secondary scientific interests in order to represent the wide diversity of the geological and geomorphological features of the region. Geosites with multiple interests were privileged;

- Representativeness: the selected geosites must have good representativeness of a geological and/or geomorphological process;

- Geographical distribution: given the aforementioned criteria, an attempt was made to give a good geographical distribution of the chosen geosites in order to range throughout the entire regional territory without overrepresenting some areas and underrepresenting others.

Detailed field surveys were performed in order to collect site-specific updated data relevant for the completion of the inventory's descriptive cards according to the guidelines by ISPRA for the inclusion of the sites in the Italian National Inventory [48].

\subsection{Quantitative Assessment of Geosites}

Quantitative assessment numerically evaluates the values of geosites through indicators, reducing the inevitable subjectivity associated with any evaluation procedure and making the results comparable. Since the pioneering methods developed in Europe in the late $1990^{\prime}$, a number of methods were published for nearly 30 years, but as of now, there is no generally accepted method cf. $[37,38]$ and references therein. Many quantitative methods are based on sets of parameters and indicators that generally refer to different values of the geosites: (i) the scientific value; (ii) the additional value (ii) the potential-foruse. A score is given to each parameter, and then the individual scores are combined to obtain a final score, or $Q$ value $[70,84]$. Other methods do not calculate a final score but separately consider each set of parameters because the criteria considered are independent of each other and because the independent numerical evaluation of each criterion enables the individual analysis of each geosite.

In the present study, the selected geosites were quantitatively assessed by applying a methodology that was specifically set up on the basis of previous works $[8,12,13,15,85]$.

The geosite value assessment is based on the following value, and corresponding criteria were set up (Tables 1-3): (i) scientific value; (ii) additional value; (iii) potential-foruse value.

Table 1. Sub-criteria used for the numerical assessment of geosite scientific value.

\begin{tabular}{|c|c|c|c|c|c|}
\hline Scientific Value & 1 & 2 & 3 & 4 & 5 \\
\hline Integrity (INT) & $\begin{array}{c}\text { Poor } \\
\text { conservation }\end{array}$ & $\begin{array}{c}\text { Partial damage, } \\
\text { integrity not } \\
\text { preserved }\end{array}$ & $\begin{array}{l}\text { Partial damage, } \\
\text { preserved integrity }\end{array}$ & Good conservation & $\begin{array}{c}\text { Very good } \\
\text { conservation }\end{array}$ \\
\hline $\begin{array}{l}\text { Representativeness } \\
\text { (REP) }\end{array}$ & $\begin{array}{c}\text { No } \\
\text { exemplarity }\end{array}$ & $\begin{array}{l}\text { Poor example } \\
\text { of process or } \\
\text { landform }\end{array}$ & $\begin{array}{c}\text { Fair example } \\
\text { of process or } \\
\text { landform }\end{array}$ & $\begin{array}{c}\text { Good example of } \\
\text { process or } \\
\text { landform }\end{array}$ & $\begin{array}{l}\text { Reference site in } \\
\text { literature for the } \\
\text { process or } \\
\text { landform }\end{array}$ \\
\hline Rareness (RAR) & Very common & Rare at a local scale & $\begin{array}{l}\text { Rare at a regional } \\
\text { scale }\end{array}$ & $\begin{array}{c}\text { Rare at a national } \\
\text { scale }\end{array}$ & $\begin{array}{c}\text { Rare at an } \\
\text { international scale }\end{array}$ \\
\hline $\begin{array}{c}\text { Secondary interests } \\
\text { (SEC) }\end{array}$ & $\begin{array}{l}\text { No secondary } \\
\text { interests }\end{array}$ & $\begin{array}{l}\text { One secondary } \\
\text { interest of poor } \\
\text { relevance }\end{array}$ & $\begin{array}{c}\text { One or more } \\
\text { secondary interests } \\
\text { of fair relevance }\end{array}$ & $\begin{array}{c}\text { One or more } \\
\text { secondary interests } \\
\text { of good relevance }\end{array}$ & $\begin{array}{c}\text { One or more } \\
\text { secondary interests } \\
\text { of great relevance }\end{array}$ \\
\hline
\end{tabular}


Table 2. Sub-criteria used for the numerical assessment of geosite additional value.

\begin{tabular}{|c|c|c|c|c|c|c|}
\hline $\begin{array}{l}\text { Additional } \\
\text { Value }\end{array}$ & & 1 & 2 & 3 & 4 & 5 \\
\hline \multirow[t]{4}{*}{$\begin{array}{c}\text { Esthetic } \\
\text { value (EST) }\end{array}$} & Naturalness & $\begin{array}{l}\text { Completely } \\
\text { modified by } \\
\text { human action }\end{array}$ & $\begin{array}{l}\text { Strongly affected } \\
\text { by human action, } \\
\text { some natural } \\
\text { features are still } \\
\text { preserved }\end{array}$ & $\begin{array}{l}\text { Moderately } \\
\text { affected by } \\
\text { human action }\end{array}$ & $\begin{array}{l}\text { Slightly affected } \\
\text { by human action }\end{array}$ & $\begin{array}{c}\text { No trace of } \\
\text { human action }\end{array}$ \\
\hline & $\begin{array}{l}\text { Panoramic } \\
\text { quality }\end{array}$ & $\begin{array}{l}\text { Site not visible } \\
\text { from any } \\
\text { viewpoint }\end{array}$ & $\begin{array}{l}\text { Site visible from } \\
\text { one viewpoint }\end{array}$ & $\begin{array}{l}\text { Site visible from } \\
\text { more than one } \\
\text { viewpoint }\end{array}$ & $\begin{array}{l}\text { Site visible at } \\
360^{\circ} \text { within a } \\
\text { close distance }\end{array}$ & $\begin{array}{l}\text { Site visible from } \\
\text { many } \\
\text { viewpoints also } \\
\text { from a great } \\
\text { distance }\end{array}$ \\
\hline & $\begin{array}{l}\text { Color } \\
\text { diversity }\end{array}$ & $\begin{array}{l}\text { No color } \\
\text { diversity }\end{array}$ & $\begin{array}{l}\text { Low color } \\
\text { diversity }\end{array}$ & $\begin{array}{l}\text { Moderate color } \\
\text { diversity }\end{array}$ & $\begin{array}{l}\text { High color } \\
\text { diversity }\end{array}$ & $\begin{array}{l}\text { Very high color } \\
\text { diversity }\end{array}$ \\
\hline & $\begin{array}{c}\text { Vertical } \\
\text { development }\end{array}$ & $\begin{array}{l}\text { Same level as } \\
\text { the } \\
\text { surrounding } \\
\text { ground }\end{array}$ & $\begin{array}{c}\text { Slightly } \\
\text { emerging from } \\
\text { the surrounding } \\
\text { ground }\end{array}$ & $\begin{array}{l}\text { Moderately } \\
\text { emerging from } \\
\text { the surrounding } \\
\text { ground }\end{array}$ & $\begin{array}{l}\text { Significantly } \\
\text { emerging from } \\
\text { the surrounding } \\
\text { ground }\end{array}$ & $\begin{array}{l}\text { Imposing feature } \\
\text { on the landscape }\end{array}$ \\
\hline \multirow[t]{2}{*}{$\begin{array}{l}\text { Cultural } \\
\text { value } \\
\text { (CULT) }\end{array}$} & $\begin{array}{l}\text { Historical } \\
\text { importance }\end{array}$ & $\begin{array}{l}\text { No historical } \\
\text { importance }\end{array}$ & $\begin{array}{c}\text { Historical } \\
\text { importance, no } \\
\text { connection to } \\
\text { geological and } \\
\text { geomorphologi- } \\
\text { cal } \\
\text { features }\end{array}$ & $\begin{array}{l}\text { Historical } \\
\text { importance with } \\
\text { connection to } \\
\text { geological or ge- } \\
\text { omorphological } \\
\text { features of the } \\
\text { site }\end{array}$ & $\begin{array}{l}\text { Local historical } \\
\text { importance with } \\
\text { connection to } \\
\text { both geological } \\
\text { and geomorpho- } \\
\text { logical features } \\
\text { of the site }\end{array}$ & $\begin{array}{c}\text { National } \\
\text { historical } \\
\text { importance with } \\
\text { connection to } \\
\text { both geological } \\
\text { and geomorpho- } \\
\text { logical features } \\
\text { of the site }\end{array}$ \\
\hline & $\begin{array}{l}\text { Archaeological } \\
\text { importance }\end{array}$ & $\begin{array}{c}\text { No } \\
\text { archaeological } \\
\text { importance }\end{array}$ & $\begin{array}{l}\text { Archaeological } \\
\text { importance, no } \\
\text { connection to } \\
\text { geological and } \\
\text { geomorphologi- } \\
\text { cal } \\
\text { features }\end{array}$ & $\begin{array}{l}\text { Archaeological } \\
\text { importance with } \\
\text { connection to } \\
\text { geological or ge- } \\
\text { omorphological } \\
\text { features of the } \\
\text { site }\end{array}$ & $\begin{array}{c}\text { Local } \\
\text { archaeological } \\
\text { importance with } \\
\text { connection to } \\
\text { both geological } \\
\text { and geomorpho- } \\
\text { logical features } \\
\text { of the site }\end{array}$ & $\begin{array}{c}\text { National } \\
\text { archaeological } \\
\text { importance with } \\
\text { connection to } \\
\text { both geological } \\
\text { and geomorpho- } \\
\text { logical features } \\
\text { of the site }\end{array}$ \\
\hline
\end{tabular}

Table 3. Sub-criteria used for the numerical assessment of geosite potential-for-use value.

\begin{tabular}{cccccc}
\hline Potential for Use & $\mathbf{1}$ & $\mathbf{2}$ & $\mathbf{3}$ & $\mathbf{4}$ & $\mathbf{5}$ \\
\hline $\begin{array}{c}\text { Accessibility } \\
\text { (ACC) }\end{array}$ & $\begin{array}{c}\text { Accessible only by } \\
\text { experts with specific } \\
\text { technical skills (e.g., } \\
\text { climbers, } \\
\text { speleologists) }\end{array}$ & $\begin{array}{c}\text { Accessible by } \\
\text { experts, but no } \\
\text { specific technical } \\
\text { skills are required }\end{array}$ & $\begin{array}{c}\text { Accessible by } \\
\text { people in good } \\
\text { physical form }\end{array}$ & $\begin{array}{c}\text { Accessible by } \\
\text { people with } \\
\text { normal movement } \\
\text { capacity }\end{array}$ & $\begin{array}{c}\text { Accessible by } \\
\text { people with } \\
\text { limited movement } \\
\text { capacity }\end{array}$ \\
\hline $\begin{array}{c}\text { Interpretative } \\
\text { potential (PIN) }\end{array}$ & $\begin{array}{c}\text { Very poor: } \\
\text { understandable only } \\
\text { by insiders }\end{array}$ & Poor & Fair & Good & $\begin{array}{c}\text { Very good: } \\
\text { understandable by } \\
\text { anyone }\end{array}$ \\
\hline
\end{tabular}

The scientific value is based on the four criteria: integrity (INT), representativeness (REP), rareness (RAR) and secondary interests (SEC). The additional value takes into account the esthetical (EST) and cultural (CULT) values. The potential-for-use is based on accessibility (ACC) and interpretative potential (PIN).

The esthetic value is the most subjective one, as it depends on the individual sensibility and preference of researchers and visitors. In the scientific literature, there has been extensive discussion on esthetic judgment [86] and references therein, and some methodologies have been set up to define the criteria for a quantitative esthetic value 
assessment, e.g., [84,87-89]. In this work, four criteria (naturalness, panoramic quality, color diversity and vertical development) were considered to assess the esthetic value, according to Reynard et al. [84] and Coratza et al. [89].

A score between 1 and 5 was attributed to each parameter, then the total scientific/ additional/potential-for-use value is the average of each set of parameters. The $Q$ value was then calculated with the weighted average of the three total values, as shown in Equation (1).

$$
\mathrm{Q}=(3 \mathrm{~Sv}+\mathrm{Av}+\mathrm{Pu}) / 5
$$

where $\mathrm{Sv}$ is the scientific value, $\mathrm{Av}$ is the additional value, and $\mathrm{Pu}$ is the potential-for-use.

\subsection{Degradation Risk Assessment of Geosites}

According to [90-93], the risk of degradation is the probability of a geosite being damaged or destroyed, i.e., losing any of the features that make it valuable as a geosite. It follows that assessment of geosites degradation risk assessment is of paramount importance in any geoconservation strategy, especially in setting an effective plan for the correct management and enhancement of geosites. The inclusion of degradation risk aspects in geoheritage, especially its assessment, is a relatively recent initiative. Despite some methods for the quantitative assessment of the degradation risk are described in the literature ([38] and references therein); however, a standard methodology that supports the recognition and prevention of threats affecting geosites is still missing.

In the present study, a first tentative methodology is proposed to evaluate the degradation risk for the Ligurian geosites. This methodology is based on the definitions of Fuertes-Gutiérrez and Fernández-Martínez [67,93], according to which the degradation risk is given by the combination of fragility-defined as the "degradation risk under present natural conditions, i.e., without the intervention of Man" [93] (p. 1) and vulnerability -defined as the "risk of destruction due to human activity [93] (p. 61). The fragility depends on the intrinsic characteristics of the geosite (e.g., type of geosite, extension, rock mass strength) and on its sensitivity to the action of natural processes (e.g., erosion, the intensity of erosive agents, slope stability). It is important to note that, in many cases, the same morphogenetic process that gave rise to a geosite is also an important risk factor for natural degradation. Vulnerability depends on numerous factors [38], such as the population density of the area surrounding the geosite, the difficulty of access, the presence of access controls or restrictions, protected areas or other territorial constraints, the proximity to anthropogenic elements that can cause degradation (mining activities, urban areas, industrial areas, etc.).

The methodology developed and applied in this study for the degradation risk assessment (Table 4) is based on the following three criteria: (i) fragility due to the same natural processes that created the geosite $(\mathrm{Fa})$; (ii) fragility due to other natural processes $(\mathrm{Fb})$; (iii) vulnerability due to anthropic actions (V).

Table 4. Sub-criteria used for the numerical assessment of geosite degradation risk.

\begin{tabular}{ccccc}
\hline Scientific Value & $\mathbf{1}$ & $\mathbf{2}$ & $\mathbf{3}$ & $\mathbf{4}$ \\
\hline $\begin{array}{c}\text { Fragility } \\
\text { due to processes that created the geosite } \\
(\text { Fa) }\end{array}$ & Low & Medium & Moderate & High \\
\hline $\begin{array}{c}\text { Fragility } \\
\text { due to other natural processes (Fb) }\end{array}$ & Low & Medium & Moderate & High \\
\hline Vulnerability (V) & Low & Medium & Moderate & High \\
\hline
\end{tabular}

For each criterion, a score was given between 1 and 4 . The total score was calculated with the weighted average of the three criteria. The heavier weight was assigned to $\mathrm{V}$ because from a management perspective; it is easier to intervene in anthropogenic actions. It was decided to assign a lower weight to $\mathrm{Fa}$ than to $\mathrm{Fb}$. The condition described for $\mathrm{Fa}$ 
is common in geomorphosites, in which the same process that has shaped the site slowly leads to its degradation or destruction. In these cases, the interest in the geosite is due more to the morphogenetic process itself than to the resulting landform.

\section{Results}

\subsection{Recognition and Selection of Geosites}

Collecting all the data of previous works, field surveying and literature review, a database of 520 "potential geosites" was compiled. From this large database, 120 sites were selected to form the inventory of geosites (Table S1A, Figure 5a) and the data collected were stored in a GIS database.

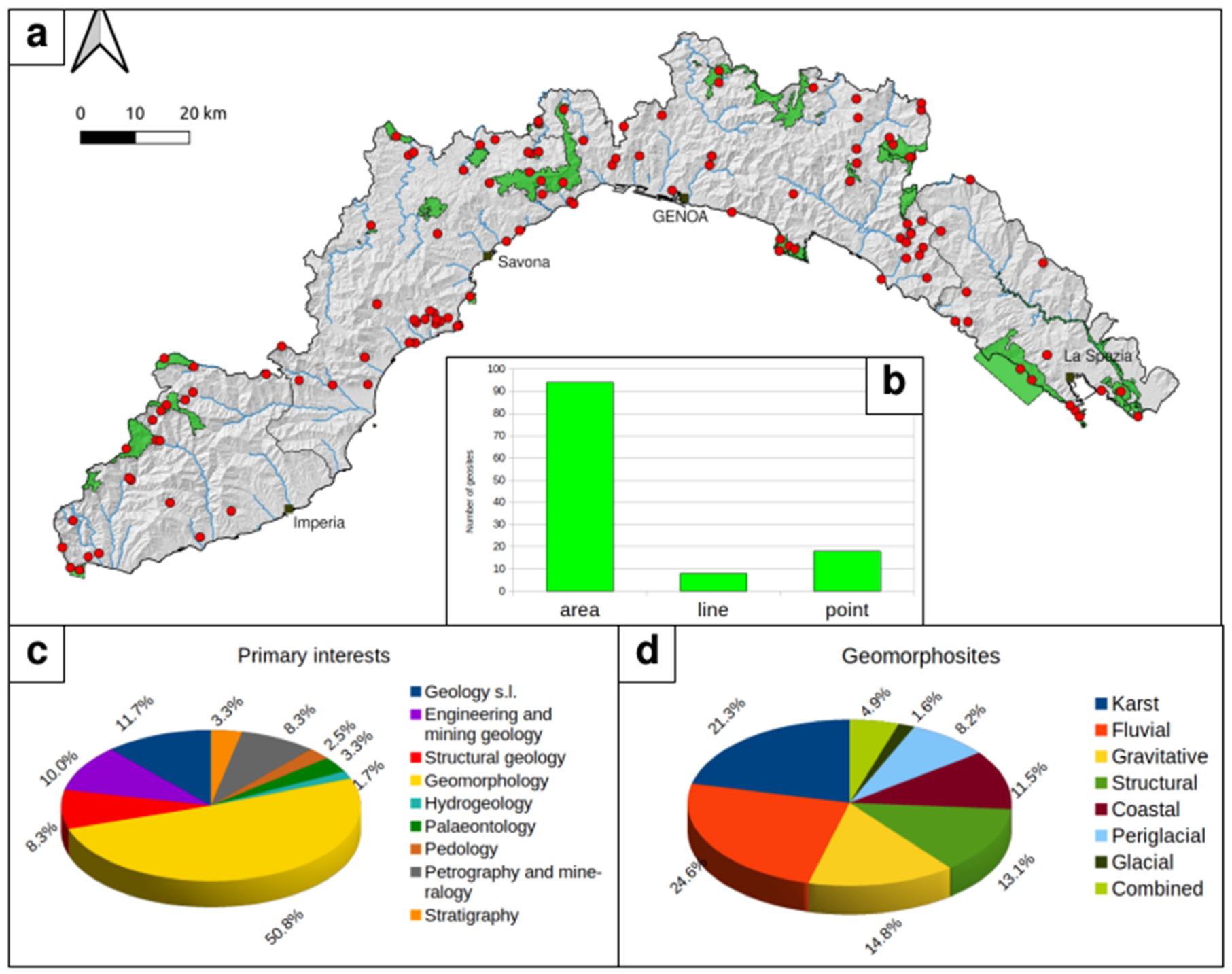

Figure 5. (a) Geographical distribution of the Ligurian geosites (red dots). In green, the main protected areas are represented. (b) Number of areal, linear, and point geosites; (c) geosites by primary interest; (d) geomorphosites by morphogenetic agent.

The inventoried geosites were classified according to their typology [93-95] and references therein (Figure 5b). Following the national guidelines by ISPRA, three typologies were considered: areal, linear and point geosites. Ninety-four geosites were classified as areal $(78.3 \%), 18$ sites as point geosites $(15 \%)$ and 8 sites as linear $(6.7 \%)$. Most sites are areal due to the survey scale (1:10.000). There are many different types of areal geosites: cliffs, karst plateaus, sinkholes, lakes, mines, quarries, landslides, rock outcrops, etc. Point geosites are mainly: sites with underground development (caves and mines); springs, 
isolated spires; pedological sites. Linear geosites are of two main types: fluvial geomorphosites (e.g., gorges) or stratigraphic sequences, usually outcropping in road cuts.

Regarding the main scientific interest, 9 different main interests were identified: geology s.l., engineering geology, structural geology, geomorphology, hydrogeology, paleontology, pedology, petrography-mineralogy and stratigraphy. The "geology s.l." category includes geosites of geological interest in a broad sense, in which relevant aspects of regional, structural and stratigraphic geology coexist.

The most represented category (Figure $5 c$ ) is that of geosites of geomorphological interest, which make up about half of the inventory (61), then there are geosites of geological latu sensu (s.l.) interest (14), engineering geology (12), structural geology (10), mineropetrographic (10), stratigraphic (7), paleontological (4), pedological (3) and hydrogeological interest (2).

Among geomorphosites, there is a good distribution between the principal morphogenetic processes that are or have been active in the Liguria Region (Figure $5 \mathrm{~d}$ ).

\subsection{Quantitative Assessment of Geosites}

The selected geosites were evaluated considering their scientific, additional and potential-for-use value. The scores associated with each of these values were combined to obtain a total score ( $Q$ value) (Table S1B). In Figure 6, geosites are divided into six $Q$ classes. Class 4 is the most represented, containing 34 geosites. In class 6, representing the highest $\mathrm{Q}$ value, there are 9 geosites. The lowest score class (class 1 ) is the least abundant, with only 5 geosites.

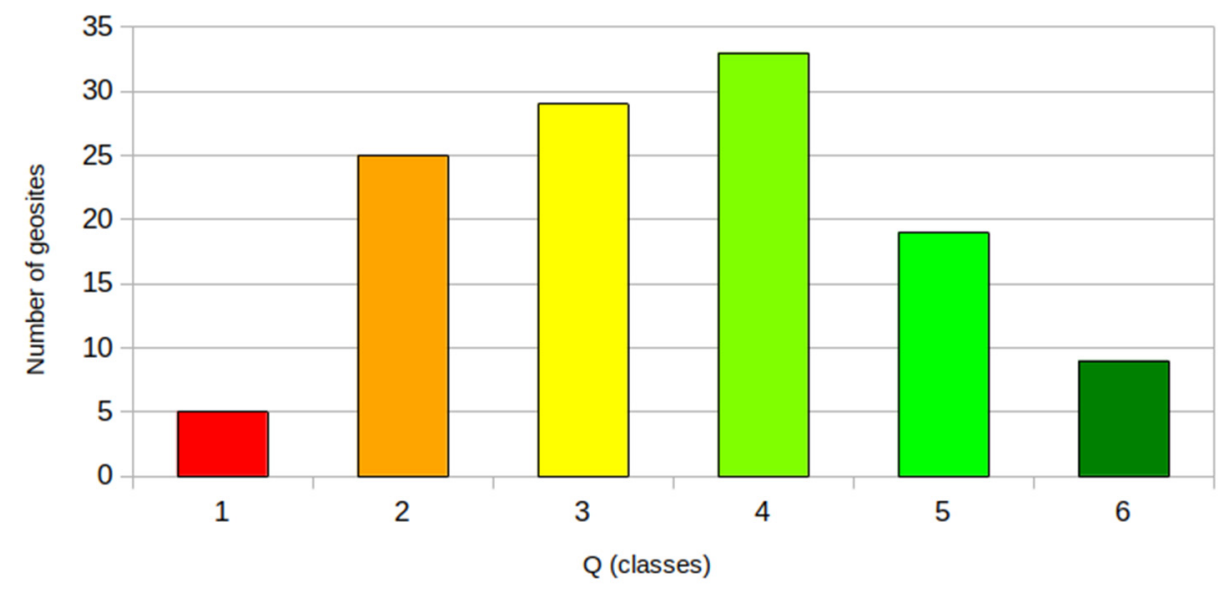

Figure 6. Geosites by $\mathrm{Q}$ value classes. Class 1: $\mathrm{Q}<3$; class 2:3 $<\mathrm{Q}<3.25$; class 3:3.25 $<\mathrm{Q}<3.50$; class 4:3.50<Q $<3.75$; class 5:3.75 $<\mathrm{Q}<4$; class 6: $\mathrm{Q}>4$.

Figure 7 shows the multivariate representation of the scores assigned in the value assessment. By observing the forms assumed by the diagrams, it is possible to make a quick comparison between the different geosites and identify those that have similar characteristics. The geosites were grouped on the basis of primary interest, which in the diagrams are shown in different colors.

In general, regardless of the type and main scientific interest, the geosites assessed show high integrity and medium to high representativeness. There are 12 geosites rare on a national scale and 73 rare on a regional scale. The scores assigned to the secondary interests are high as this parameter was taken into account in the first selection to set up the inventory of geosites.

The multivariate representation (Figure S1a) can be useful for identifying similarities between geosites with the same primary interest. The most represented categories (geology s.l. and geomorphology) have rather variable diagrams. The diagrams concerning geosites of engineering geology often have a round shape due to the fact that no parameters take 
on particularly low scores. Geosites of hydrogeological interest show average scientific value, rather low esthetic and cultural values, but high potential-for-use. The geosites of paleontological interest have a high or medium-high scientific value, medium-high use potential, medium-high esthetic value but low cultural value. The geosites of pedological interest show a similar situation, with medium-high scientific value and low additional and potential-for-use values. A similar situation occurs for geosites of petrographical interest.

a

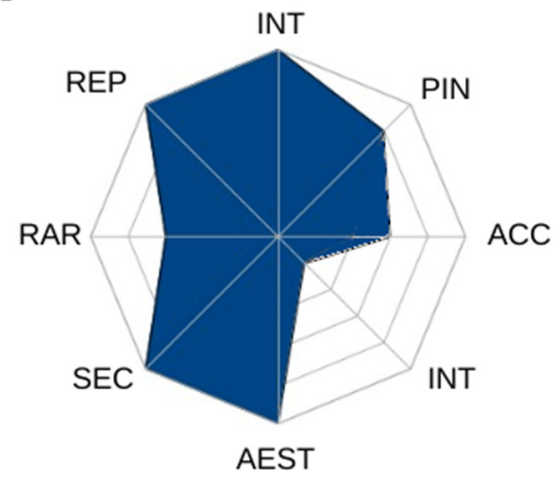

$\mathrm{Fa}$

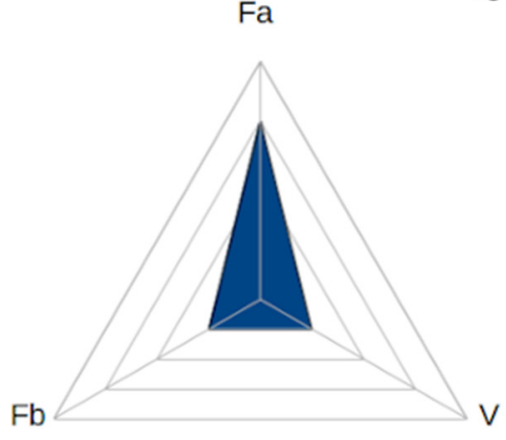

Figure 7. Multivariate representation of the value (a) and degradation risk (b) scores for the "Portovenere cliffs" geosite. The parameters and their significance are explained in Tables 1-4.

\subsection{Degradation Risk Assessment of Geosites}

The degradation risk of geosites was evaluated considering three parameters concerning geosites fragility and vulnerability. The scores associated with each of these values were combined to obtain a total score (Table S1C).

In Figure 8, the total values were divided into four classes (low, medium, moderate and high degradation risk). Most geosites (61) are located in class 2, corresponding to a medium degradation risk. Only 7 geosites show low vulnerability; 40 geosites are of medium vulnerability, as many as 59 geosites (about half of the total) are of moderate vulnerability, and 14 geosites are highly vulnerable.

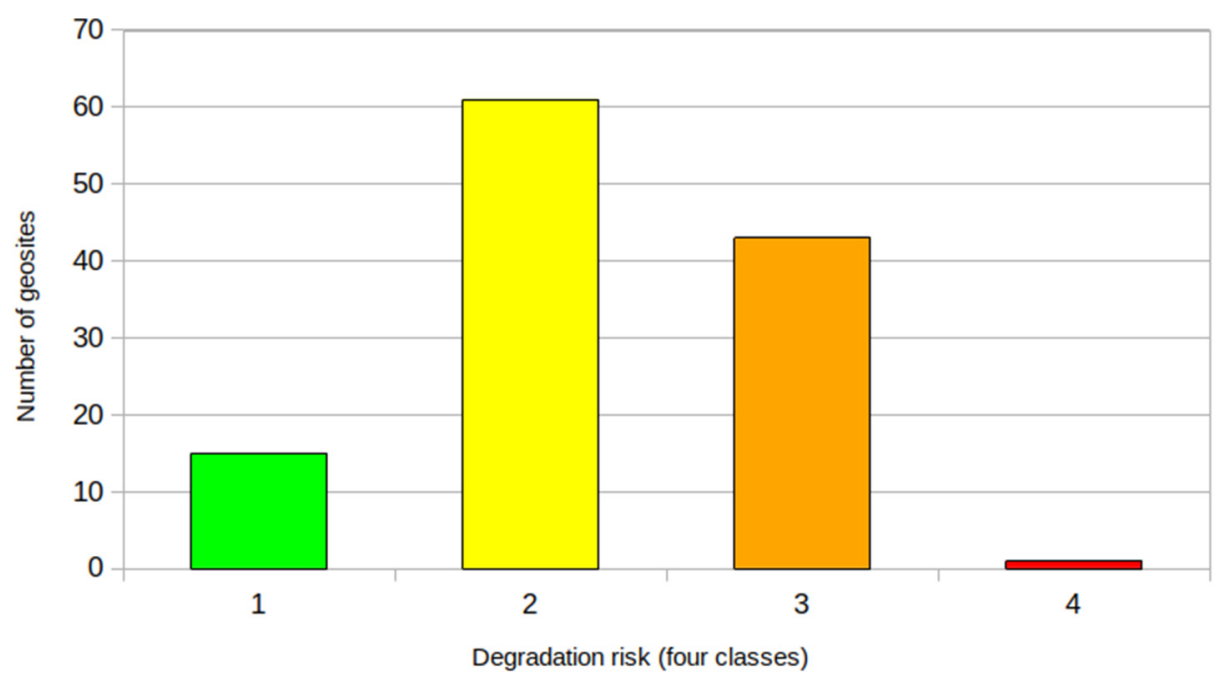

Figure 8. Geosites by total degradation risk classes: $1=$ low; $2=$ medium; $3=$ moderate; $4=$ high.

The parameter $\mathrm{Fa}$, linked to the intrinsic fragility of the geosite and to the natural processes that shaped it, tends to be relatively high only for geomorphosites or for sites with strong geomorphological connotations.

The multivariate representation shows the scores assigned to the parameters of the degradation risk assessment (Figure S1b). The aforementioned differences can be seen: 
the diagrams concerning geosites of geomorphological interest assume rather variable forms; to a lesser extent, the variability is also present in geosites with primary geological s.l. structural and engineering geology interests. The diagrams relating to geosites of pedological, petrographic and paleontological interest have shapes very similar to a flattened triangle due to the fact that $\mathrm{Fa}$ assumes the minimum score, while $\mathrm{Fb}$ and $\mathrm{V}$ assume medium-high values.

\section{Discussion}

This research carried out through field surveys, and the review of scientific literature and technical reports has shown the great number of geosites in the Liguria Region, which reflect its particular geographical, geological and geomorphological features.

It is no coincidence that Liguria hosts one of the most active UNESCO Global Geoparks (Beigua Geopark), and the main regional protected areas have Earth Science features as the main point of interest: ophiolites in the case of the Beigua and Aveto natural parks; conglomerates and coastal landforms in the Portofino park; flysch and limestones in the Alpi Liguri park; flysch and conglomerates in the Antola park. Some other protected areas were established to protect and promote sites of significant geological interest: Tana dell'Orpe cave in the Bric Tana natural park, the "mushroom", and the badlands in the Piana Crixia natural park; the fossils of Rio Torsero natural park.

There is a correspondence between areas with a high concentration of geosites and the main protected areas of Liguria (Figure 5a). Especially the natural parks of the Ligurian Alps, Beigua, Aveto and Portovenere show a high concentration of geosites. The Beigua Natural Park, part of the UNESCO Global Geopark Network, hosts by far the largest number of geosites among the Ligurian parks (8 in the natural park area, 16 in the entire geopark area). The only area with a high concentration of geosites that does not correspond to a park area is the territory of Finale Ligure (SV). The project to make it a natural park, born in the 1980s and also promoted by the reorganization of regional protected areas in 1995, never took off and is still under debate.

The quantitative value assessment has shown that the inventoried geosites have a generally high $Q$, varying from 2.90 to 4.33 . The nine geosites with the highest Q (Figure 9) are among the best-known geosites of the Liguria Region. All of them are already exploited for tourism: the Gambatesa Mine has become a mining museum, and most of the other geosites are reached by well-known hiking trails.

The highest esthetic value is obtained by imposing features on the landscape, i.e., cliffs, pinnacles, islands, etc.: some of the best known are the aforementioned Palmaria and Tino Islands, the Portovenere cliffs, the Castell'Ermo dolomitic towers. High cultural value can be due to historical importance (Castello della Pietra) or archaeological importance (Balzi Rossi caves, Arma delle Manie). The latter geosites show important links between the archaeological and geological-geomorphological features and can therefore be considered archaeogeosites sensu [31].

The risk of degradation associated with a geosite is another index of paramount importance, which must be taken into account in the preparation and implementation of a management plan [38]. The assessment of the degradation risk was performed with a quantitative method that considered three parameters: fragility due to the natural processes that generated the geosite, fragility linked to natural processes not connected with the geosite's genesis, and vulnerability to anthropic impact. The final score was calculated with the weighted average of these three parameters.

In general, the total degradation risk of the geosites is on average (51\% of the inventory) or moderate $(36 \%)$ values. One geosite, the Libiola Mine, falls into a high-risk category. The Libiola Mine is an abandoned copper mine, known for its environmental problems due to acid mine drainage processes [96,97].

There is a connection between the degradation risk and the dimensions of a geosite, e.g., [93-95]. Figure 10 shows the number of points, linear and areal geosites per class of degradation risk. The count of geosites by type is expressed as a percentage in order to 
make the data comparable. The histogram highlights how the areal extension of the geosite influences the degradation risk: most of the areal geosites are in the category of average degradation risk; the similar situation for linear geosites, with much less dispersed data; on the other hand, most point geosites belong to the moderate degradation risk category.
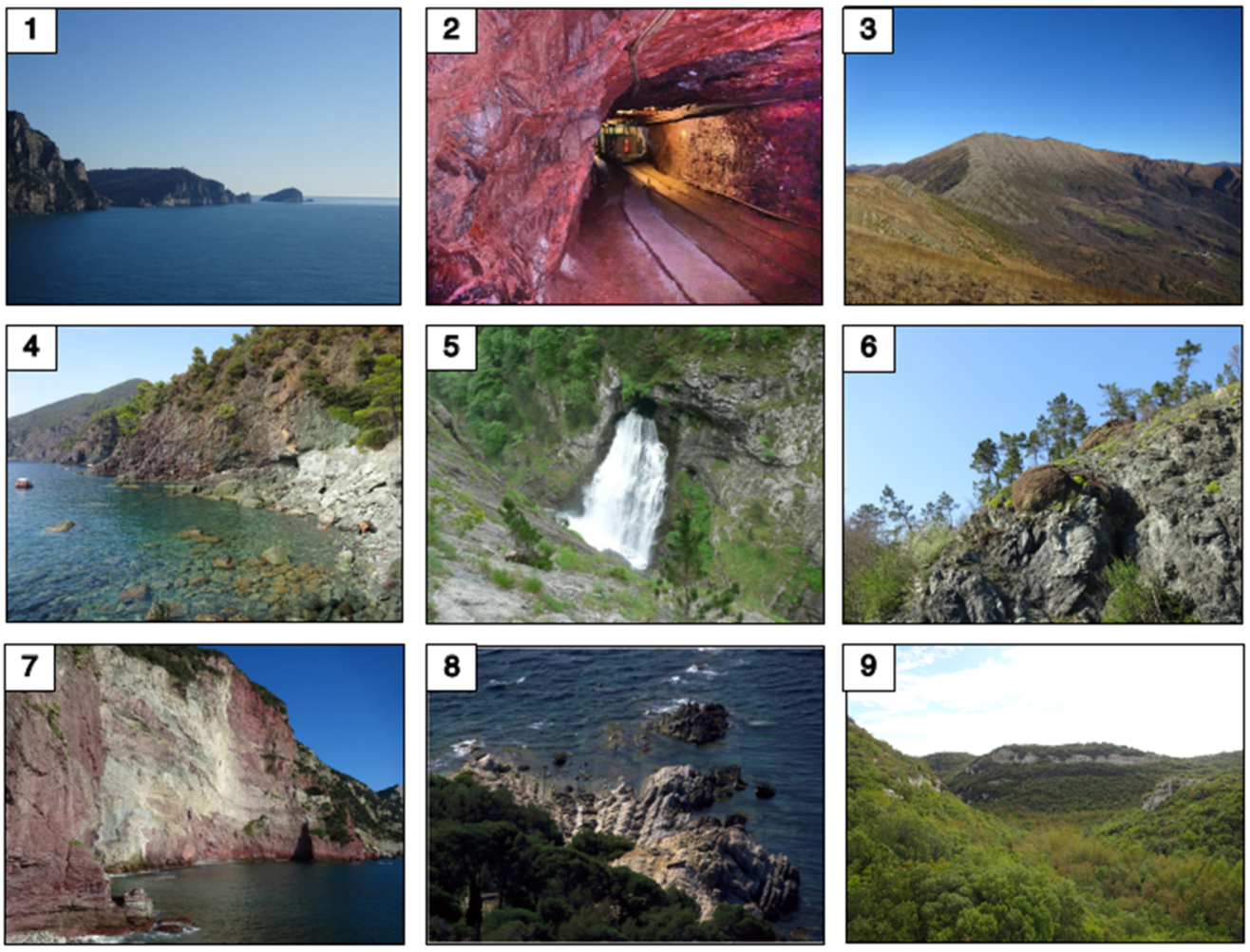

Figure 9. The nine geosites with $\mathrm{Q}>4$. (1) Palmaria and Tino islands; (2) Gambatesa mine; (3) Mt. Ramaceto; (4) Framura basaltic cliffs; (5) Fascette Gorge; (6) Lherzolitic spheroids of Lago dei Gulli; (7) Portovenere cliffs; (8) Capo Mortola nummulitic limestones; (9) St Bernardino karst plateau.

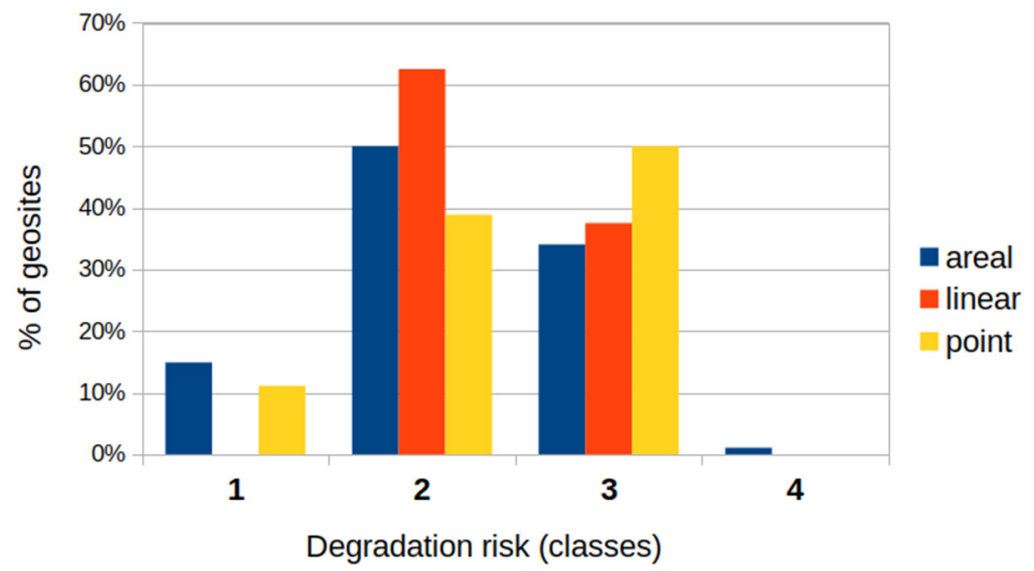

Figure 10. Percentage of areal, linear and point geosites per degradation risk classes. $1=$ low; $2=$ medium; $3=$ moderate; $4=$ high .

The results obtained in this study are in line with the results of research carried out in different Italian regions for the geosites inventory (e.g., Friuli Venezia Giulia [98], Emilia-Romagna [99], Puglia [100] that testify the great Italian geodiversity and the great abundance of geomorphosites. 


\section{Conclusions}

This research has led to the identification of 120 geosites in the Liguria region (Northern Italy), whose value and degradation risk was quantitatively assessed. The quantitative value assessment allows pinpointing the most suitable sites for geotourism promotion, the most important geosites from a scientific, esthetic or cultural point of view. The degradation risk assessment carried out for the first time in Liguria has shown the more fragile and vulnerable geosites, supporting the regional administration concerning which geoconservation and management actions should be implemented.

Tourism plays a major role in the Ligurian economy: accommodation facilities have recorded an average of 15 million attendances per year in the last five years [101]. However, tourism and recreational activities focus mainly on the seaside (78.4\% of tourists) and on cultural heritage (e.g., historical cities and towns; $75.7 \%$ ). Only in recent years, the Ligurian geoheritage has seen growing attention, with the institution of the Beigua Geopark, the Gambatesa and Masso mining museums and geoscience-related activities being undertaken in other protected areas.

This research demonstrates that, despite its small geographical scale, the Liguria region is characterized by a rich and valuable geoheritage. Geosite evaluation provides useful information, allowing for effective management strategies and geotourism enhancement. Geological and geomorphological features can be relevant in developing slow and sustainable tourism fruition, thanks to a better understanding of geological and geomorphological context and processes. The connection of geoheritage features with landscape and cultural (i.e., artistic, historical, archaeological, etc.) features should lead to the creation of a network of thematic routes, stimulating tourists to discover lesser-known areas of great interest, thus diminishing anthropic pressure on very crowded coastal areas. Geotourism, therefore, represents an important tool that can lead to significant economic benefits.

The occurrence of many different processes, landforms and landscapes in a small space and the high-density of the population make Liguria a fragile and vulnerable region. Because of this, the evaluation of the degradation risk, carried for the first time on Ligurian geosites, provides fundamental information for environmental management planning and geoconservation. Geosites' conservation is a complex issue that should take into account both natural active processes and anthropic action. Fragility evaluation helps to individuate active geosites: dynamic sites, susceptible to changes depending on the intensity, the speed and the frequency of the process that shaped them. Landforms and processes may be monitored by means of photographic and topographic surveys, shedding light on the evolution of active geosites. In some cases, active processes represent actual threats to visitors (e.g., rock falls from a cliff), requiring more complex intervention to reduce the risk factors.

Vulnerability evaluation helps to pinpoint the most susceptible sites to human action. While actions against natural processes are often very difficult or even useless, anthropic pressure is easier to control. In this respect, it can be useful to monitor public affluence to vulnerable sites, to identify any impact on their integrity and consequently take action. Geosites' size plays a major role in this case, with small sites (e.g., point geosites) being able to stand lower anthropic pressure than large areal sites.

From the 1990s onwards, numerous studies and reports about geosites in the Liguria region have been carried out, e.g., [13,49-51], sometimes only in limited portions of the regional territory. Despite the great abundance of data to start from, however, many of these studies did not follow a systematic and common inventory methodology neither a quantitative assessment method. This has led to a delay in the definition of a Regional inventory of geosites, which to date has not been approved yet by the regional and national authorities. This study, whose methodological approach was shared with the Regional authority and with ISPRA, which manages the national inventory, also has allowed systematizing and purifying all the data and reports from previous activities, completing, where necessary, the accompanying documentation. 
The results of this research will serve as the basis for the approval of the Regional Inventory of Geosites and, after appropriate reviews, for the update of the National Inventory of Geosites managed by ISPRA. Moreover, the data collected will provide the necessary knowledge for decision-makers to guide actions regarding (i) effective conservation of the rich regional geological heritage through its inclusion in territorial planning strategies; (ii) inclusion of selected geosites in geotourism and educational activities, using geological contexts or peculiarities as key elements to develop safe and eco-compatible tourism also in less-familiar areas.

Supplementary Materials: The following are available online at https:/ / www.mdpi.com/2071-105 0/13/4/2346/s1, Table S1A: Inventory of geosites of the Liguria region, Table S1B: Results of geosite value assessment, Table S1C: Results of geosite degradation risk assessment, Figure S1: multivariate representation of the results of geosite value (a) and degradation risk (b) assessment.

Author Contributions: Conceptualization, F.P.; methodology, P.C.; validation, F.P.; formal analysis, A.F.; data curation, A.F.; writing—original draft preparation, A.F.; writing—review and editing, F.F. and P.C.; supervision, P.C.; project administration, F.F.; funding acquisition, F.F. All authors have read and agreed to the published version of the manuscript.

Funding: This research received no external funding.

Institutional Review Board Statement: Not applicable.

Informed Consent Statement: Not applicable.

Data Availability Statement: Not applicable.

Acknowledgments: The authors are grateful to anonymous referees for their useful comments and suggestions to improve the original draft.

Conflicts of Interest: The authors declare no conflict of interest.

\section{References}

1. Brocx, M.; Semeniuk, V. Geoheritage and geoconservation-History, definition, scope and scale. J. R. Soc. West. Aust. 2007, 90, 53-87.

2. Burek, C.; Prosser, C. The history of geoconservation: An introduction. Geol. Soc. Lond. Spec. Publ. 2008, 300, 1-5. [CrossRef]

3. Gray, M. Geodiversity: Valuing and Conserving Abiotic Nature, 2nd ed.; Wiley Blackwell: Chichester, UK, 2013.

4. Reynard, E.; Brilha, J. Geoheritage: Assessment, Protection, and Management; Elsevier: Amsterdam, The Netherlands, 2018.

5. Gray, M. Geodiversity: Valuing and Conserving Abiotic Nature, 1st ed.; Wiley, J., Ed.; The Atrium, Southern Gate: Chichester, $\mathrm{UK}, 2004$.

6. Gray, M. Geodiversity: The backbone of geoheritage and geoconservation. In Geoheritage: Assessment, Protection, and Management; Reynard, E., Brilha, J., Eds.; Elsevier: Amsterdam, The Netherlands, 2018; pp. 13-25.

7. Newsome, D.; Dowling, R.K. Geotourism: The Tourism of Geology and Landscape; Goodfellow Publishers: Oxford, UK, 2010.

8. Brilha, J. Inventory and quantitative assessment of geosites and geodiversity sites: A review. Geoheritage 2016, 8, 119-134. [CrossRef]

9. Van den Ancker, H.J.A.M.; Jungerius, P.D. Geodiversity, geoheritage and geoconservation along the Dutch coast. Ned. Geogr. Stud. 2004, 325, 63-72.

10. Brock, M.; Semeniuk, V. Coastal geoheritage: Encompassing physical, chemical and biological processes, landforms, and other geological features in the coastal zone. J. R. Soc. West. Aust. 2009, 92, 243-260.

11. Brock, M.; Semeniuk, V. Coastal geoheritage: A hierarchical approach to classifying coastal types as a basis for identifying geodiversity and sites of significance in Western Australia. J. R. Soc. West Aust. 2010, 93, 81-113.

12. Cappadonia, C.; Coratza, P.; Agnesi, V.; Soldati, M. Malta and Sicily joined by geoheritage enhancement and geotourism within the framework of land management and development. Geosciences 2018, 8, 253. [CrossRef]

13. Coratza, P.; Vandelli, V.; Fiorentini, L.; Paliaga, G.; Faccini, F. Bridging terrestrial and marine geoheritage: Assessing geosites in Portofino Natural Park (Italy). Water 2019, 11, 2112. [CrossRef]

14. Margiotta, S.; Parise, M. Hydraulic and geomorphological hazards at wetland geosites along the eastern coast of Salento (SE Italy). Geoheritage 2019, 11, 1655-1666. [CrossRef]

15. Selmi, L.; Coratza, P.; Gauci, R.; Soldati, M. Geoheritage as a tool for environmental management: A case study in Northern Malta (Central Mediterranean Sea). Resources 2019, 8, 168. [CrossRef]

16. Garavaglia, V.; Pelfini, M.; Bollati, I. The influence of climate change on glacier geomorphosites: The case of two Italian glaciers (Miage Glacier, Forni Glacier) investigated through dendrochronology. Géomorphologie 2010, 2, 153-164. [CrossRef] 
17. Bosson, J.B.; Reynard, E. Geomorphological heritage, conservation and promotion in high-alpine protected areas. Eco. Mont 2012, 4, 13-22. [CrossRef]

18. Reynard, E.; Coratza, P. The importance of mountain geomorphosites for environmental education. Examples from the Italian Dolomites and the Swiss Alps. Acta Geogr. Slov. 2016, 56, 291-303. [CrossRef]

19. Hoblea, F.; Delannoy, J.J.; Jaillet, S.; Ployon, E.; Sadier, B. Digital Tools for Managing and Promoting Karst Geosites in Southeast France. Geoheritage 2014, 6, 113-127. [CrossRef]

20. Ballesteros, D.; Fernández-Martínez, E.; Carcavilla, L.; Jiménez-Sánchez, M. Karst cave geoheritage in protected areas: Characterisation and proposals of management of deep caves in the Picos de Europa National Park (Spain). Geoheritage 2019, 11, 1919-1939. [CrossRef]

21. Antić, A.; Tomić, N.; Marković, S. Karst geoheritage and geotourism potential in the Pek River lower basin (Eastern Serbia). Geogr. Pann. 2019, 23, 32-46. [CrossRef]

22. Liso, I.S.; Chieco, M.; Fiore, A.; Pisano, L.; Parise, M. Underground geosites and caving speleotourism: Some considerations, from a case study in Southern Italy. Geoheritage 2020, 12, 13. [CrossRef]

23. Ávila, S.P.; Cachão, M.; Ramalho, R.S.; Botelho, A.Z.; Madeira, P.; Rebelo, A.C.; Cordeiro, R.; Melo, C.; Hipólito, A.; Ventura, M.A.; et al. The Palaeontological Heritage of Santa Maria Island (Azores: NE Atlantic): A Re-evaluation of Geosites in GeoPark Azores and Their Use in Geotourism. Geoheritage 2016, 8, 155-171. [CrossRef]

24. Migon, P.; Pijet-Migon, E. Overlooked geomorphological component of volcanic geoheritage-Diversity and perspectives for tourism industry, Pogórze Kaczawskie region, SW Poland. Geoheritage 2016, 8, 333-350. [CrossRef]

25. Nemeth, K.; Moufti, M.R. Geoheritage Values of a Mature Monogenetic Volcanic Field in Intra-continental Settings: Harrat Khaybar, Kingdom of Saudi Arabia. Geoheritage 2017, 9, 311-328. [CrossRef]

26. Różycka, M.; Migoń, P. Customer-Oriented Evaluation of Geoheritage—on the Example of Volcanic Geosites in the West Sudetes, SW Poland. Geoheritage 2018, 10, 23-37. [CrossRef]

27. Pica, A.; Vergari, F.; Fredi, P.; Del Monte, M. The Aeterna Urbs geomorphological heritage (Rome, Italy). Geoheritage 2016, 8, 31-42. [CrossRef]

28. Erikstad, L.; Nakrem, H.A.; Markussen, J.A. Protected geosites in an urban area of Norway, inventories, values and management. Geoheritage 2018, 10, 219-229. [CrossRef]

29. Sacchini, A.; Ponaro, M.I.; Paliaga, G.; Piana, P.; Faccini, F.; Coratza, P. Geological landscape and stone heritage of the Genoa walls Urban park and surrounding area (Italy). J. Maps 2018, 14, 528-541. [CrossRef]

30. Cimmino, F.; Faccini, F.; Robbiano, A. Stones and coloured marbles of Liguria in historical monuments. Per. Miner. 2004, 73, 71-84.

31. Melelli, L.; Bizzarri, R.; Baldanza, A.; Gregori, L. The etruscan “Volumni Hypogeum" archeo-geosite: New sedimentological and geomorphological insights on the tombal complex. Geoheritage 2016, 8, 301-314. [CrossRef]

32. Fidelibus, M.D.; Pellicani, R.; Argentiero, I.; Spilotro, G. The geoheritage of the water intake of Triglio ancient aqueduct (Apulia region, Southern Italy): A lesson of advanced technology insensitive to climate changes from an ancient geosite. Geoheritage 2018, 10, 327-339. [CrossRef]

33. Sardella, R.; Iurino, A.D.; Mecozzi, B.; Sigari, D.; Bona, F.; Bellucci, L.; Coltorti, M.; Conti, J.; Lembo, G.; Muttillo, B.; et al. Grotta Romanelli (Lecce, Southern Italy) between past and future: New studies and perspectives for an archaeo-geosite symbol of the Palaeolithic in Europe. Geoheritage 2019, 11, 1413-1432. [CrossRef]

34. Brzezińska-Wójcik, T.; Skowronek, E. Tangible Heritage of the Historical Stonework Centre in Brusno Stare in the Roztocze Area (SE Poland) as an Opportunity for the Development of Geotourism. Geoheritage 2020, 12, 10. [CrossRef]

35. Geremia, F.; Bentivenga, M.; Palladino, G. Environmental geology applied to geoconservation in the interaction between geosites and linear infrastructures in South-Eastern Italy. Geoheritage 2015, 7, 33-46.

36. Fuertes-Gutiérrez, I.; García-Ortiz, E.; Fernández-Martínez, E. Anthropic Threats to Geological Heritage: Characterization and Management: A Case Study in the Dinosaur Tracksites of La Rioja (Spain). Geoheritage 2016, 8, 135-153. [CrossRef]

37. Reynard, E.; Coratza, P.; Regolini-Bissig, G. Geomorphosites; Verlag Dr. Friedrich Pfeil: Munich, Germany, 2009.

38. Brilha, J. Geoheritage: Inventories and evaluation. In Geoheritage: Assessment, Protection and Management; Reynard, E., Brilha, J., Eds.; Elsevier: Amsterdam, The Netherlands, 2018; pp. 69-86.

39. The United Nations Educational, Scientific and Cultural Organization (UNESCO). Geoparks Programme: A new initiative to promote a global network of geoparks safeguarding and developing selected areas having significant geological features. In Proceedings of the 156th UNESCO Executive Board, Paris, France, 4 March 1999.

40. Amorfini, A.; Bartelletti, A.; Ottria, G. Enhancing the Geological Heritage of the Apuan Alps Geopark (Italy). In From Geoheritage to Geoparks. Geoheritage, Geoparks and Geotourism (Conservation and Management Series); Errami, E., Brocx, M., Semeniuk, V., Eds.; Springer: Cham, Switzerland, 2015.

41. Lima, E.A.; Machado, M.; Guerreiro, M.; Nunes, J.; Costa, M.P. Geological heritage management in small islands: The example of the Azores UNESCO Global Geopark (Portugal). Geoheritage 2018, 10, 659-671. [CrossRef]

42. Sá, A.A.; Rocha, D. Arouca UNESCO Global Geopark: Geomorphological Diversity Fosters Local Development. In Landscapes and Landforms of Portugal. World Geomorphological Landscapes; Vieira, G., Zêzere, J., Mora, C., Eds.; Springer: Cham, Switzerland, 2020. 
43. Sinnyovsky, D.; Sachkov, D.; Tsvetkova, I.; Atanasova, N. Geomorphosite characterization method for the purpose of an aspiring geopark application dossier on the example of Maritsa Cirque Complex in Geopark Rila, Rila Mountain, SW Bulgaria. Geoheritage 2020, 12, 26. [CrossRef]

44. Vieira, G.; de Castro, E.; Gomes, H.; Loureiro, F.; Fernandes, M.; Patrocínio, F.; Firmino, G.; Forte, J. The Estrela Geopark-From Planation Surfaces to Glacial Erosion. In Landscapes and Landforms of Portugal. World Geomorphological Landscapes; Vieira, G., Zêzere, J., Mora, C., Eds.; Springer: Cham, Switzerland, 2020.

45. Brancucci, G.; Gisotti, G.; Zarlenga, F. Italy. In Geoheritage in Europe and its Conservation; Wimbledon, W.A.P., Smith-Meyer, S., Eds.; ProGEO: Oslo, Norway, 2012; pp. 188-199.

46. Giovagnoli, M.C. Geoheritage in Italy. In Landforms and Landforms of Italy. World Geomorphological Landscapes; Soldati, M., Marchetti, M., Eds.; Springer: Cham, Switzerland, 2017.

47. Italian UNESCO Global Geoparks. Available online: http://www.unesco.org/new / en/natural-sciences/environment/earthsciences/unesco-global-geoparks/list-of-unesco-global-geoparks/italy (accessed on 21 February 2021).

48. Inventario Nazionale dei Geositi. Available online: http:/ / sgi2.isprambiente.it/geositiweb/ (accessed on 16 January 2021).

49. Brancucci, G.; Grillo, R.; Menozzi, B.; Paliaga, G. Censimento dei geomorfositi nella provincia di Savona. In Geositi e Dintorni; Brancucci, G., Ed.; Colombo Grafiche: Genova, Italy, 2004; pp. 17-99.

50. Burlando, M.; Firpo, M.; Queirolo, C.; Rovere, A.; Vacchi, M. From geoheritage to sustainable development: Strategies and perspectives in the Beigua Geopark (Italy). Geoheritage 2011, 3, 63-72. [CrossRef]

51. Poggi, E.; Queirolo, C.; Burlando, M.; Poggi, F. Geosites inventory in the Liguria Region (Italy) and in Beigua Geopark: Updating activities. Rend. Online Soc. Geol. Ital. 2013, 28, 121-124.

52. Köppen, W. Das geographische System der Klimate. In Handbuch der Klimatologie; Köppen, W., Geiger, R., Eds.; Borntraeger: Berlin, Germany, 1936.

53. Fratianni, S.; Acquaotta, F. The Climate of Italy. In Landscapes and Landforms of Italy. World Geomorphological Landscapes; Soldati, M., Marchetti, M., Eds.; Springer: Cham, Switzerland, 2017.

54. Capponi, G.; Crispini, L.; Federico, L.; Malatesta, C. Geology of the Eastern Ligurian Alps: A review of the tectonic units. Ital. J. Geosci. 2016, 135, 157-169. [CrossRef]

55. Giammarino, S.; Capponi, G.; Crispini, L.; Giglia, G.; Piazza, M. Carta Geologica della Liguria—Scala 1:200.000; LAC: Firenze, Italy, 2002.

56. Mosca, P.; Polino, R.; Rogledi, S.; Rossi, M. New data for the kinematic interpretation of the Alps-Apennines junction (Northwestern Italy). Int. J. Earth Sci. (Geol. Rundsch.) 2009, 99, 833-849. [CrossRef]

57. Molli, G.; Crispini, L.; Malusà, M.; Mosca, P.; Piana, F.; Federico, L. Geology of the Western Alps-Northern Apennine junction area: A regional review. J. Virtual Explor. 2010, 36, 1-49. [CrossRef]

58. Fanucci, F; Nosengo, S. Rapporti fra neotettonica e fenomeni morfogenetici del versante marittimo dell'Appennino Ligure e del margine continentale. Boll. Soc. Geol. It. 1977, 96, 41-51.

59. Progetto IFFI (Inventario dei Fenomeni Franosi in Italia) [Inventory of Landslide Phenomena in Italy]. Available online: https:/ / www.isprambiente.gov.it/it/progetti/cartella-progetti-in-corso/suolo-e-territorio-1/iffi-inventario-dei-fenomenifranosi-in-italia (accessed on 17 January 2021).

60. Faccini, F.; Federico, L.; Torchio, S.; Roccati, A.; Capponi, G.; Crispini, L. A mountain slope deformation in an alpine metaophiolitic massif (Ligurian Alps, Italy). J. Maps 2020. [CrossRef]

61. Faccini, F.; Benedettini, A.; Firpo, M.; Perasso, L.; Poggi, F. Land-management and planning in karst areas: The ligurian case-study (Italy). Rend. Online Soc. Geol. It. 2012, 21, 611-613.

62. Firpo, M.; Guglielmin, M.; Queirolo, C. Relict blockfields in the Ligurian Alps (Mount Beigua, Italy). Permafr. Periglac. Process. 2006, 17, 71-78. [CrossRef]

63. Cattaneo Vietti, R.; Albertelli, G.; Aliani, S.; Bava, S.; Bavestrello, G.; Benedetti Cecchi, L.; Bianchi, C.N.; Bozzo, E.; Capello, M.; Castellano, M.; et al. The Ligurian Sea: Present status, problems and perspectives. Chem. Ecol. 2010, 26, 319-340. [CrossRef]

64. Mastronuzzi, G.; Aringoli, D.; Aucelli, P.; Baldassarre, A.; Bellotti, P.; Bini, M.; Biolchi, S.; Bontempi, S.; Brandolini, P.; Chelli, A.; et al. Geomorphological map of the Italian coast: From a descriptive to a morphodynamic approach. Geogr. Fis. Dinam. Quat. 2017, 40, 161-195.

65. Brandolini, P.; Cappadonia, C.; Luberti, G.M.; Donadio, C.; Stamatopoulos, L.; Di Maggio, C.; Faccini, F.; Stanislao, C.; Vergari, F.; Paliaga, G.; et al. Geomorphology of the Anthropocene in Mediterranean urban areas. Prog. Phys. Geogr. 2019, 44, 461-494. [CrossRef]

66. Paliaga, G.; Luino, F.; Turconi, L.; De Graff, J.V.; Faccini, F. Terraced landscapes on Portofino Promontory (Italy): Identification, geo-hydrological hazards and management. Water 2020, 12, 435. [CrossRef]

67. Fuertes-Gutiérrez, I.; Fernández-Martínez, E. Geosites Inventory in the Leon province (Northwestern Spain): A tool to introduce Geoheritage into Regional Environmental Management. Geoheritage 2010, 2, 57-75. [CrossRef]

68. Del Monte, M.; Fredi, P.; Pica, A.; Vergari, F. Geosites within Rome city center (Italy): A mixture of cultural and geomorphological heritage. Geogr. Fis. Dinam. Quat. 2013, 36, 241-257.

69. Garcia, M.d.G.; Del Lama, E.; Martins, L.; Mazoca, C.E.M.; Bourotte, C.L.M. Inventory and assessment of geosites to stimulate regional sustainable management: The northern coast of the state of São Paulo, Brazil. Acad. Bras. Ciênc. 2019, 91. [CrossRef] [PubMed] 
70. Bruschi, V.M.; Cendrero, A. Geosite evaluation: Can we measure intangible values? Ital. J. Quat. Sci. 2005, 18, $293-306$.

71. Coratza, P.; Giusti, C. Methodological proposal for the assessment of the scientific quality of geomorphosites. Ital. J. Quat. Sci. 2005, 18, 303-313.

72. Pralong, J.-P.; Reynard, E. A proposal for a geomorphological sites classification depending on their tourist value. Il Quat. 2005, $18,313-319$.

73. Zouros, N. Geomorphosite assessment and management in protected areas of Greece. Case study of the Lesvos Island-coastal geomorphosites. Geogr. Helv. 2007, 62, 69-180. [CrossRef]

74. Pereira, P.; Pereira, D.; Caetano Alves, M.I. Geomorphosite assessment in Montesinho Natural Park (Portugal). Geogr. Helv. 2007, 62, 159-168. [CrossRef]

75. Rybár, P. Assessment of attractiveness (value) of geotouristic objects. Acta Geoturistica 2010, 1, $13-21$.

76. Vujicic, M.D.; Vasiljevic, D.E.; Markovic, S.B.; Hose, T.A.; Lukic, T.; Hadzic, O.; Janicevic, S. Slankamen villages preliminary geosite assessment model (GAM) and its application on Fruska Gora Mountain, potential geotourism destination of Serbia. Acta Geogr. Slov. 2011, 51, 361-377. [CrossRef]

77. Fassoulas, C.; Mouriki, D.; Dimitriou-Nikolakis, P.; Iliopoulos, G. Quantitative assessment of geotopes as an effective tool for geoheritage management. Geoheritage 2012, 4, 177-193. [CrossRef]

78. Kubalíková, L. Geomorphosite assessment for geotourism purposes. Czech. J. Tour. 2013, 2, 80-104. [CrossRef]

79. Štrba, L.; Rybár, P.; Baláž, B.; Molokáč, M.; Hvizdák, L.; Kršák, B.; Lukáč, M.; Muchová, L.; Tometzová, D.; Ferenčíková, J. Geosite assessments: Comparison of methods and results. Curr. Issues Tour. 2015, 18, 496-510. [CrossRef]

80. De Wever, P.; Alterio, I.; Egoroff, G.; Cornée, A.; Bobrowsky, P.; Collin, G.; Duranthon, F.; Hill, W.; Lalanne, A.; Page, K. Geoheritage, a National Inventory in France. Geoheritage 2015, 7, 205-247. [CrossRef]

81. Szepesi, J.; Ésik, Z.; Soós, I.; Németh, B.; Sütő, L.; Novák, T.J.; Harangi, S.; Lukáks, R. Identification of Geoheritage Elements in a Cultural Landscape: A Case Study from Tokaj Mts, Hungary. Geoheritage 2020, 12, 89. [CrossRef]

82. Brancucci, G.; Paliaga, G. Atlante dei Geositi della Liguria; Grafiche Amadeo: Imperia, Italy, 2008.

83. Faccini, F.; Gabellieri, N.; Paliaga, G.; Piana, P.; Angelini, S.; Coratza, P. Geoheritage map of the Portofino Natural Park (Italy). J. Maps 2018, 14, 87-96. [CrossRef]

84. Reynard, E.; Fontana, G.; Kozlik, L.; Scapozza, C. A method for assessing scientific and additional values of geomorphosites. Geogr. Helv. 2007, 62, 148-158. [CrossRef]

85. Reynard, E.; Perret, A.; Bussard, J.; Grangier, L.; Martin, S. Integrated approach for the inventory and management of geomorphological heritage at the regional scale. Geoheritage 2016, 8, 43-60. [CrossRef]

86. Kirillova, K.; Fu, X.; Lehto, X.; Cai, L. What makes a destination beautiful? Dimension of tourist aesthetic judgement. Tour. Manag. 2014, 42, 282-293. [CrossRef]

87. Ruban, D.A.; Sallam, E.S.; Ermolaev, V.A.; Yashalova, N.N. Aesthetic value of colluvial blocks in geosite-based tourist destinations: Evidence from SW Russia. Geosciences 2020, 10, 51. [CrossRef]

88. Miljković, D.; Božić, S.; Miljković, L.; Marković, S.B.; Lukić, T.; Jovanović, M.; Bjelajac, D.; Vasiljević, D.A.; Vujičić, M.D.; Ristanović, B. Geosite assessment using three different methods; a comparative study of the Krupaja and the Zagubica Springs-Hydrological heritage of Serbia. Open Geosci. 2018, 10, 192-208. [CrossRef]

89. Coratza, P.; Galve, J.P.; Soldati, M.; Tonelli, C. Recognition and assessment of sinkholes as geosites: Lessons from the Island of Gozo (Malta). Quaest. Geogr. 2012, 31, 25-35. [CrossRef]

90. Carcavilla, L.; López Martínez, J.; Durán Valsero, J.J. Patrimonio geológico y geodiversidad: Investigación, conservación, gestión y relación con los espacios naturales protegidos; Cuadernos del Museo Geominero: Madrid, Spain, 2007.

91. Cendrero, A. El patrimonio geológico. Ideas para su protección, conservación y utilización. In El patrimonio Geológico. Bases para su Valoración, Protección, Conservación y Utilización, Serie Monografías del Ministerio de Obras Públicas, Transportes y Medio Ambiente; Ministerio de Obras Públicas. Transportes y Medio Ambiente: Madrid, Spain, 1996; pp. 17-27.

92. Cendrero, A. Propuestas sobre criterios para la clasificación y catalogación del patrimonio geológico. In El Patrimonio Geológico. Bases para su Valoración, Protección, Conservación y Utilización; Serie Monografías del Ministerio de Obras Públicas, Transportes y Medio Ambiente; Ministerio de Obras Públicas, Transportes y Medio Ambiente: Madrid, Spain, 1996; pp. $29-38$.

93. Fuertes-Gutiérrez, I.; Fernández-Martínez, E. Mapping geosites for geoheritage management: A methodological proposal for the Regional Park of Picos de Europa (León, Spain). Environ. Manag. 2012, 50, 789-806. [CrossRef] [PubMed]

94. Marchetti, M.; Coratza, P.; Carton, A. Guidelines for geomorphological sites mapping: Examples from Italy. Géomorpholohie Relief Process. Environ. 2005, 3, 209-218.

95. Coratza, P.; Regolini-Bissig, G. Methods for mapping geomorphosites. In Geomorphosites; Reynard, E., Coratza, P., Regolini-Bissig, G., Eds.; Verlag Dr. Friedrich Pfeil: Munich, Germany, 2009.

96. Dinelli, E.; Lucchini, F.; Fabbri, M.; Cortecci, G. Metal distribution and environmental problems related to sulphide oxidation in the Libiola copper mine area (Ligurian Apennines, Italy). J. Geochem. Explor. 2001, 74, 141-152. [CrossRef]

97. Marescotti, P.; Carbone, C.; Comodi, P.; Frondini, F.; Lucchetti, G. Mineralogical and chemical evolution of ochreous precipitates from the Libiola Fe-Cu-sulfide mine (Eastern Liguria, Italy). Appl. Geochem. 2012, 27, 577-589. [CrossRef] 
98. Cucchi, F.; Finocchiaro, F.; Muscio, G. Gesositi del Friuli Venezia Giulia. Dipartimento di Scienze Geologiche, Ambientali e Marine dell'Università degli Studi di Trieste e dal Museo Friulano di Storia Naturale di Udine. Available online: https://www.regione. fvg.it/rafvg/cms/RAFVG/ambiente-territorio/tutela-ambiente-gestione-risorse-naturali/FOGLIA201/FOGLIA16/ (accessed on 21 February 2021).

99. Cazzoli, M.A.; Centineo, M.C.; Daniele, G. Censimento, Tutela e Valorizzazione del Patrimonio Geologico Regionale. I Geositi dell'Emilia-Romagna-Rivista Storie Naturali. 29-33. Available online: https://ambiente.regione.emilia-romagna.it/it/geologia/ geologia/geositi-paesaggio-geologico/pdf/i_geositi_dell_Emiliaromagna.pdf (accessed on 21 February 2021).

100. Mastronuzzi, G.; Simone, O. L'individuazione Dei Siti, il Rilevamento e la Redazione Della Scheda. In Ricognizione e Verifica dei Geositi e Delle Emergenze Geologiche della Regione Puglia; Regione Puglia: Bari, Italy, 2017; pp. 28-32.

101. Osservatorio Turistico Regionale. Available online: https://www.regione.liguria.it/homepage/turismo/osservatorio-turisticoregionale.html (accessed on 20 January 2021). 